\title{
"My Hideous Progeny": Creative Monstrosity in the Works of Kiki Smith, Abigail Lane, and Cindy Sherman
}

\author{
Maria Antónia Sousa Monteiro da Cunha Lima \\ University of Évora; \\ University of Lisbon Centre for English Studies, Lisbon, Portugal
}

\begin{abstract}
The expression "My Hideous Progeny” is widely known to be taken from Mary Shelley's preface to the revised edition of Frankenstein (1831), in which she wrote, of the novel itself and of its creature, Frankenstein's monster. This paper argues that, if the monster is seen not only as the product of Frankenstein's workshop of filthy creation, but also as the child from whom Frankenstein as parent recoils in horror; the works of Kiki Smith, Abigail Lane, and Cindy Sherman, created out of body parts, may also be considered hideous progenies of female creativity. Like Mary Shelley's gothic novel, the body, in the work of these three women artists, is not only the raw material of their art, but also the screen on which we project our bad dreams. Through the art of Smith, Lane, and Sherman, we can certainly feel the shudder of body horror that ripples through the Gothic canon from Frankenstein, whose manmade monster's yellow skin barely covered the work of muscles and arteries beneath. Departing from their artistic examples, we will be able to perceive how the monstrous feminine in contemporary art can be grounded in a very famous hallmark work of Gothic literature.
\end{abstract}

Keywords: creative monstrosity, Frankenstein, Mary Shelley, Kiki Smith, Abigail Lane, Cindy Sherman

\section{Introduction}

The expression "My Hideous Progeny" is widely known to be taken from Mary Shelley's preface to the revised edition of Frankenstein (1831), in which she wrote, of the novel itself and of its creature, Frankenstein's monster, “And now once again I bid my hideous progeny go forth and prosper” (Shelley, 1996, p. 173). If the monster is seen not only as the product of Frankenstein's workshop of filthy creation, but also as the child from whom Frankenstein as parent recoils in horror; the works of Kiki Smith, Abigail Lane and Cindy Sherman, created out of body parts, may also be considered hideous progenies of female creativity.

Like Mary Shelley's gothic novel, the body, in the work of these three women artists, is not only the raw material of their art, but also the screen on which we project our bad dreams, because as Grunenberg (1997) notes, in Gothic: Transmutations of Horror in Late 20th Century Art, postmodern Gothic takes the shape of “formless, horrendous images of mutilated and rotting bodies with limbs covered in boils and wounds,' of disjoined body parts uncannily "transformed into nightmares" (p. 168). Through the art of Smith, Lane and Sherman, we can certainly feel the shudder of body horror that ripples through the Gothic canon from Frankenstein (1831), whose manmade monster's "yellow skin barely covered the work of muscles and arteries

Maria Antónia Sousa Monteiro da Cunha Lima, Ph.D., assistant professor, Department of Linguistics and Literatures, University of Évora; University of Lisbon Centre for English Studies. 
beneath" (Shelley, 1996, p. 34). This monstrosity is common to Kiki Smith’s Virgin Mary (1992) ${ }^{1}$, a sculpture where the woman's nude body is flayed, the skin removed to reveal bare muscle tissue, showing that the monstrous feminine in contemporary art can be grounded in a very famous hallmark work of Gothic literature.

Presenting a vision of catastrophic creation, arising artificially from fragments, Frankenstein reflects the drama of the creative process showing that its author was not very trusting of creativity, the imagination, intellectual ambition and writing itself, a fact that originated a self-referential work, where literary creation, as every other art form, can be seen as a process of assembling and combining pre-existing elements. In her introduction to the 3rd edition of Frankenstein, Mary Shelley concludes that: "Invention... does not consist in creating out of the void, but out of chaos; the materials must, in the first place, be afforded: it can give form to dark, shapeless substances but cannot bring into being the substance itself” (Shelley, 1996, p. 171). This essential limitation is present in every creative act, which establishes the inevitable connections between the anxieties of authorship and the anxieties of maternity, especially when the fear of producing hideous monsters is common to both, due to the uncertainties involved in the creative process, especially if these are attained by unnatural modes of reproduction. The result of a hideous creation can only be a monstrous body that challenges ideals of classical beauty and teaches us to live with uncertainty in a world without moral absolutes. As Botting (1995) concludes in an introduction to Frankenstein, monsters function as "indices of deformity" fulfilling a socially regulative function. Consequently, revealing monstrosity or deformity, can regulate social attitudes and behavior (p. 16). In Frankenstein's Shadow, Baldick (1987) also acknowledges the versatility of this literary myth recognizing "how its various facets refer back to common and continuous anxieties, to genuine causes for alarm in the monstrous and uncontrollable tendencies of the modern world” (p. 9). According to Peter Brooks, Frankenstein "concerns an exotic body with a difference, a distinct perversion from the tradition of desirable objects" (as cited in Baldick, 1987, p. 81) - this being origin of every hideous creation. As a result, creation is intimately associated with the concept of transgression and quite often these appear to be the same thing.

The transgressive aspects of the monstrous body imply that it participates in the dissolution of all categories of thought which justifies its deviation from the norm and its unstable and always shifting identity. In this paper, we should take into account these three women artists' attraction for ugliness which was directly expressed by Sherman, when she stated that "a degree of hyper-ugliness has always fascinated me. Things that were considered unattractive and undesirable interested me particularly. And I do find things like that really beautiful” (as cited in Cruz, 2001, p. 490). Reflecting on the simultaneous effect of attraction and repulsion created by monstrous images and trying to explain how we can take pleasure from what horrifies us, in The Philosophy of Horror, Carroll (1990) defends that horror attracts because anomalies command attention or elicit curiosity concluding that the impossible being does disgust, but that disgust is part of an overall narrative address which is not pleasurable, but whose potential pleasure depends on the confirmation of the existence of monster as a being that violates, defies or problematizes standing cultural classifications (p. 186).

\section{Creative Monstrosity as a “Transmedia” Phenomenon}

In spite of producing art-horror objects in different media, Kiki Smith, Abigail Lane, and Cindy Sherman are connected by a common affect their art raises: The emotion of horror produced by the presence of monstrous images and forms which allows us to deal with their creative monstrosity as a "transmedia" phenomenon. As

${ }^{1}$ Retrieved from http://www.culturevulture.net/ArtandArch/kikismith.htm 
Carroll (1990) reminds us, "art-horror" is meant to refer to the product of a genre that crystallized around the time of the publication of Frankenstein. It is characterized by the presence of horrific imagery, monsters and by a certain affect it intended to encourage. This led Carroll (1990) to conclude that "the cross-art, cross-media genre of horror takes its title from the emotion it characteristically or rather ideally promotes; this emotion constitutes the identifying mark of horror” (p. 14). Confounding the distinctions between real flesh and its artificial manipulation, the art of these three women artists provokes the affect of horror as powerfully as Frankenstein monster. Victor Frankenstein's reaction to his creation can well express the power of this emotion: "Now that I had finished, the beauty of the dream vanished and disgust filled my heart. Unable to endure the aspect of the being I had created, I rushed out of the room, unable to compose my mind to sleep” (Shelley, 1996, p. 34). This sense of horror is created because horrific creatures are psychological or physically threatening, inspiring revulsion. They are also impure due to their combinatory nature generated by several categorical contradictoriness. As Carroll (1990) observed "one structure for the composition of horrific beings is fusion” (p. 43) which turns the Frankenstein monster into a fusion figure, arising from distinct bodies, along with electrical attachments and different brains. For that reason, creative monstrosity depends on the construction of creatures that transgress categorical distinctions such as inside/outside, animal/human, animate/inanimate, living/death, human/object, and many other juxtapositions and amalgamation of dichotomies we can find in the works of Kiki Smith, Abigail Lane, and Cindy Sherman.

More human than his creator, the monster reveals not only the paradox of creation but also his very uncanny nature that results from his life being composed of dead human bodily parts, an assemblage that is at once natural and artificial, an animated being born from inanimate matter. In Das Unheimliche, Freud (1919) describes the uncanny as something that appears to be alive, in spite of being strangely silent and motionless. Thus, when dealing with uncanniness, we deal with the uncertainty whether a lifeless object might not in fact be animate. In The Body in Contemporary Art, O’Reilly (2009) observes that:

Dolls and puppets may transcend the physical limits of the hidebound human performer, but they can only represent life, being devoid of vitality itself. It is the failure of dolls, dummies, puppets and mannequins to be alive, even while they look so much like the "real thing", that explains their disquieting aura. (pp. 157-159)

We can find this uncanny effect especially in Keith Edmier's hideous creations of human beings and plants, Robert Gober's realist legs intercepted by walls, Abigail Lane’s wax corpses or Cindy Sherman's assemblages of body parts, which led Grunenberg (1997) to conclude that all these examples "attest to a crisis of coherent selfhood" (p. 163). In a project entitled The Uncanny (1993 \& 2004) directed by Mike Kelley, it was possible to perceive the dual quality of this fusion figure as both animated signifier and inert substance, a condition common to many contemporary figurative pieces of art by Charles Ray, Kiki Smith, the Chapmans and many others present in an exhibition where anatomical models, blow-up sex dolls, toys, and forensic photographs were displayed.

\section{Kiki Smith’s Frankenstein Fantasy: The Sculptor as Monster Maker}

In Kiki Smith's work, the presence of the uncanny can be felt in her life-size figures in wax and bronze presenting naked female bodies in disturbing and provocative visceral poses. A lot of her work is about separating form from matter in which developed her kind of Frankensteinien fascination with the biological mechanics of the human anatomy. Smith (1995) confessed that she made several sculptures of the internal 
organs, when she was frightened of the outside because she does not like personality. This explains her desire to talk about the generic experience of the body without becoming specific to definite people. Her focus on anonymous feminine forms rather than particular personalities led her to examine female archetypes in religion, mythology, and folklore. These anonymous bodies are far from the ideal nudes that populate much of art history, because they are at once visceral and dignified, familiar yet strange remaining quietly introspective in spite of their debased states. Their ambiguity reflects the nonheroic terms with which they were created by exposing their dual aspects of vulnerability and strength. This duality also defines Smith's creative process characterized by maintaining in balance between her scientific and folklore knowledge, which allows her to preserve a unique vision of the body that can range from clinical to primal.

Very concerned with mortality and interested in the subjects of birth and death, Smith called herself Kiki Frankenstein. In fact, she seemed to be as seduced by anatomy and natural science as Victor Frankenstein which led her to confess that:

In making work that's about the body, I'm playing with the indestructibility of life, where life is this ferocious force that keeps propelling us. At the same time... you can just pierce it and it dies. I'm always playing between these two extremes. (Smith, 1995)

Following the death of her father in 1980, the themes of mortality and decay were very present in Kiki Smith's work. She offered clinical treatments of human organs in her sculptures of the period, including Glass Stomach (1985), Untitled (Heart) (1986), and Second Choice (1987), a bowl of lungs, liver, spleen, and heart. Hand in Jar (1983) — a latex hand, covered in algae and submerged in a mason jar filled with water—resulted in a morbid and poetic sculpture. The mad scientist's laboratory is evoked by the disembodied part, showing a preserved decadence and an inevitable sense of isolation due to the long periods of disconnection with the outside world. In a very insightful work about the artist, Posner (2005) observes that:

Smith's intense focus on death and decomposition spurred her creative woman compulsion to symbolically revitalize dead matter through her art. She refers to this impulse as her Frankenstein fantasy, likening herself to the mad scientist who builds composite bodies out of dismembered parts in a morbid, yet idealistic, attempt to heal and reanimate the dead. (p. 13)

Posner (2005) also considers that Smith is the example of the sculptor as monster maker, because she has the capacity of taking damaged bodies and making them whole. In this way Smith can be compared to a perverse creator who is able to associate a perversely modern creation tale with the ancient biblical story, never stopping producing artistic acts of reanimation. Posner (2005) underlined that Smith believes that one of her primary mission as sculptor is to repair Cubism's fractured forms, concluding that:

The arthistorical counterpart to her Dr. Frankenstein-like ambitions is best expressed in her relationship to Cubism. Smith is troubled and perplexed by the Cubists' revolutionary shattering of the human figure into a shifting array of faceted forms during the early part of this century. (p. 13)

Therefore, it is natural that Smith's main artistic purpose is concentrated in mending our fractured existence through the careful assembling of dispersed and lost parts of ourselves. Some of her hauntingly anthropomorphic puppets, in which her role as an artist is to metaphorically heal and reanimate the dead, allude to Smith's Frankenstein fantasy. We can feel this artistic purpose reflected in her main topics such as anatomy, self-portraiture, nature, and female iconography. This interest in themes of birth and regeneration encompasses 12 illustrations for Tillman's book Madame Realism Complex (1992), for which Smith created drawings 
ranging from abstract designs suggestive of anatomical parts to a depiction of sperm swimming in a circular pattern. Considering the physical self as the primary means of experiencing the world, Smith (1995) depicts the fragmented body, exposing organs, and body parts in a shockingly and nonhierarchical way. Her intention strives to show how our body is perverted, mutated or corrupted by the dangerous forces of society, science, technology, and medicine. Frankenstein personifies this primal fear of having our body invaded by unknown forces that can totally subvert and violate our identities. This explains that, for Smith (1995):

Frankenstein is an allegory of what our body is now-a composite body where you've got your brother's kidney, somebody's else eyes, and a slew of surgical implants. People generally think of their body as their fortress, their landscape for being here, but this is rapidly becoming less and less so.

The interest in the effects of a technologically advanced society on the human existence can also be compared to Mary Shelley's premonitions and anxieties about the Industrial Revolution which led to the visual shock created by a monster, in some aspects more human than its creator. In Women Artists in the 20th and 21st century, Grosenick (2001) observes that Kiki Smith's works unite past and future with a view to making the individual's role in the world more comprehensible, concluding that "she creates a new feeling for nature and the human body, reanimates its significance in a technologically and scientifically oriented world, and provokes reflection with shocking but also poetic images” (p. 505). In this respect, Smith (1995) confessed she was trying to make sense of the process of deep changes produced by technology which affected our sense of boundaries and the definitions of who and what we are, having stated that:

All the ways technology is changing the body, where we now have transplants, artificial organs, and skin being grown from the circumcised foreskins of penises, and all the new ideas of reproduction it has created, including surrogate mothers, artificial inseminations, test-tube babies, hysterectomies, and abortions, have numerous ramifications in the way people view their lives. (Smith, 1995, Retrieved from http://www.jca-online.com/ksmith.html)

Intending to investigate skin, hair, and the full-scale body, Smith concentrates on depictions of the female form, challenging the tradition of male artists exploitation of the female body as an erotic subject. Her visceral sculptural work, constituted by bodies in states of abjection, is determined by a tension between their delicate and beautiful materiality and the shockingly primal acts they depict. Untitled (1999) represents a life-size nude man and woman modeled in wax hanging in despair with their skin mottled with bruises and letting their bodily fluids stream freely from them. Smith's interest in anatomy has less to do with the body's appearance than with its processes, failures, and traumas. Her abject figures reflect a generalized psychic pain rather than a specific didactic or political position. They can be produced in a certain social and cultural context, but they transcend their time and place to acquire a universal meaning associated with psychic and physical pain and become symbols of suffering endured by human beings. For this reason, they possess an unforgettable intensity which is the case of Blood Pool (1993) a sculpture of a woman crouched in the fetal position with her rib cage exposed. In an interview, Smith (1995) explained that she was inspired to create this work from her experience as an emergency medical technician, because she learnt that when people die, the person loses internal pressure and everything falls down, organs and everything. Thus you can tell how long somebody has been dead by the pooling of blood in the body. She even got a model of a spine from Carolina Biological Supply Company. Her famous Virgin Mary (1992), a religious figure exhibited as an anatomical model, resulted from Smith's visits to a medical school for physical therapy, where art students could study the cadavers and view the dissection of bodies. In spite of adopting forms of scientific objectification in her anatomical studies, Smith's work also 
explores implausible relations between human and animal — as in Born (2002), in which a full-grown woman emerges from the birth canal of a deer recalling the carnality of Greek myths. This suggests that, in her work, scientific and folkloric knowledge can have the same importance.

\section{Abigail Lane's Uncanny Creations}

In Abigail Lane's work we can also perceive the presence of the uncanny in its power to transform the familiar, often the domestic, into the unsettling and strange. She executes her work in a range of media, including film, posters, and sculptural installation. Together with Damien Hirst, Gary Hume, and Sarah Lucas she was a co-curator of the Freeze show, which is seen as the inauguration of what later became known as Britart. In Art From the UK (2001) which documents an important exhibition at the Goetz Collection in Munich, Abigail's work is presented together with some other very original young British artists including Mona Hatoum, Sam Taylor-Wood, Rachel Whiteread, Willie Doherty, Tracey Emin, Douglas Gordon, Angela Bulloch, and Sarah Lucas, who created an art that is innovative and challenging - from Mona Hatoum's surprising and complex mixture of media, to Rachel Whiteread's inverted spaces, to Sam Taylor-Wood's explorations of the erotic entanglements of people in closed spaces. In spite of being contemporary, Abigail's work is based on late Victorian displays such as séances, circus imagery, magic shows, and also includes wax replicas of bodily fragments suspended from the ceiling. She tries to give form to the illusive and intangible world of the psyche creating a "funhouse-mirror reflection" of the life of the mind in Tomorrows World. Yesterdays Fever (Mental Guests Incorporated) (2001), which extends her concern with the fantastical, the Gothic and the uncanny through a trio of arresting and theatrical installations based around film projections. Color photographs made in 1997, picture people in rooms, the images are made uncanny by stuffed wild animals lurking outside windows and doors. Lane has also drawn on our fascination with detective, supernatural and horror stories. In the installation The Incident Room (1993), the head and arms of a waxwork woman, lit by lamps, emerge from a pile of earth like a corpse at a crime scene. Grunenberg (1997) observed that in “Abigail Lane’s carefully staged crime scene, The Incident Room (1993), voyeuristic conventions of the male gaze (as epitomized in Marcel Duchamp’s peepshow of Étant Donné, 1946-1966) are undermined” (p. 165). This happens because the female wax mannequin surfaces from a pile of earth in a fake floor, surrounded by photographic lamps and accompanied by a fabricated newspaper report. Grunenberg (1997) also underlined that Lane is more interested in the construction of complex narratives and intricate detective stories with indirect clues and evidence than in a sensationalist spectacle of murder, rape, or torture (for that her mise en scène is too ordered, the corpse's skin too clean, willingly betraying its artificiality). The spectator loses his power over reality, because the "base materialism" of the female body withdraws itself from the objectification through the voyeuristic gaze. Also in her solo show at the Institute of Contemporary Arts, London in 1995, she invited the visitor to unravel a fictional murder story. At her exhibition at the Victoria Miro Gallery, London, held in the autumn of 2001, Lane exhibited a set of painted film posters for her own unfinished film projects, and a garden shed. Peering inside, we could see a plume of smoke rising from a pair of shoes. It recalled the film The Wizard of $\mathrm{Oz}$ (1939), a cozy reminder of childhood, but also summoned up horrifying photographs of the charred remains of bodies that supposedly spontaneously combusted.

\section{Cindy Sherman's Grotesques and the Aesthetic of Ugliness}

If Victor Frankenstein assembled his monster from parts of corpses collected from charnel-houses and 
dissecting rooms, Cindy Sherman's grotesques create monstrosities from different plastic body parts she found in medical catalogues of anatomy. Her monstrous-feminine results from the combination of many weird and totally unerotic objects laid out to capture the mass production of stereotypes of femininity which seem to convey the ironic message that creation is impossible without the use of prototypes; identity lies in appearance, not in reality. Therefore she portrays the female body as monstrously sexualized through an amalgam and fusion of genital prostheses and fragmented mannequin parts as in Untitled \#250, Untitled \#263,Untitled \#264 (1992), etc.. The strange associations of these images create a kind of theatrical grotesque where mannequins, prostheses, dummies, and erotic paraphernalia are arranged into disturbing pictures that reflect critically on today's voyeuristic dealings with physicalness and sexuality. Manipulated mannequins in obvious pornographic poses create a macabre theatre of memory connected to private acts of voyeurism which usually make people very uncomfortable. Her pictures refer to stereotypical erotic and pornographic models from mass culture and high art without producing their effects, which means that she takes these familiar poses and defamiliarizes them creating a deep visual disorientation. This sensation is created by a certain comic realism in her work which produces a crisis of category and meaning, subverting the culturally conceded boundaries of male/female, gay/straight, organic/inorganic, beauty/ ugliness, recognition/misrecognition giving origin to fusion figures and exposing our culture's fears and desires as well as the monstrous image in Frankenstein. This subversion is also applied to the artistic, cinematic, or popular media genres used by Sherman - the B movie, the magazine centerfold, the fashion spread, the fairy tale, old master paintings, pornography, surrealist photography, and horror film props because, as Smith (2001) well observed:

Constantly interweaving the real and the artificial, both in her imagery and her choice of genres, Sherman's enthusiastic engagement with the grotesque mocks the conventions of these genres by exaggerating their modes of artifice, offering a stunningly lurid portrayal of the artifacts of the monstrous. (p. 29)

The uncanniness of Sherman's images asks us to interrogate the fascination, repulsion, and disgust that we feel for the grotesque. The body is out of control as a creature which seems not to be dominated by its creator (Untitled \#314E, Untitled \#314F, 1994). The result is a simulacrum in its hyperbolic artificiality, but the aesthetical effect is ambiguous like in Frankenstein, proving that the monstrous creation is human as well as artificial. Like Mary Shelley's hideous progeny, in Sherman's works the inanimate has become animate, underlining their uncanny power and the artist's obsession with death and mortality. A strong sense of death permeates her work, something she has also in common with Victor Frankenstein who believed that "To examine the causes of life, we must first have a recourse to death" (Shelley, 1996, p. 30). In the middle of the 1980's, Sherman grappled with the aesthetic of ugliness and posed acts of violence, monsters, putrefaction and death. Her large-sized Disgust Pictures show horrifying scenes with rats, vomit, pus, mold and corpses. All these offer another parallelism with Victor Frankenstein's sensitivity because it was important for him to "observe the natural decay and corruption of the human body” (Shelley, 1996, p. 30). In The Monstrous-Feminine Film, Feminism, Psychoanalysis, Creed (1993) drew upon Julia Kristeva's theory of abjection as well as more familiar Freudian-Lacanian models to present a psychoanalytic reading of the female monster in horror films. Creed's interest in imagery and themes of female monstrosity can be useful to understand why abjection is a problem of borders being symbolized by imagery of confused or transgressed borders. Obsessive fixation on depiction of the bodily ejects such as "blood, vomit, saliva, sweat, tears and putrefying flesh" (Creed, 1993, p. 10) can lead to the conclusion that the female body, being a signifier for "the border", signifies the abject state of anxiety about 
boundaries of the body, which also allows to consider the maternal figure as abject, as something impure, something very similar to a fusion being like Frankenstein monster.

Sherman's most demanding images were part of a retrospective entitled Horror and Surrealist Pictures (1994-1996) and constituted by works that have been compared to paintings by Hieronymous Bosch, Arcimboldo, and Goya, in particular Goya's Los Caprichos and his famous The Sleep of Reason Produces Monsters (1797-1799), because as Smith (2001) concluded: "Like Goya, Sherman succeeds in parodying representations of the social—-the roles, archetypes, and vanglorious and malignant desires that we create and perpetuate brilliantly unleashing the monsters produced by the sleep of reason” (p. 29). These works are intensely claustrophobic, saturated with sadness and disillusionment, being divided into two categories: the mast portraits; and photographed arrangements of mannequins, toys, rotten garbage, broken domestic goods and unidentifiable waste products. They all challenge conventional conceptions of beauty and demand explorations of the dark depths of the imagination and subconscious, evoking thoughts and sensations that usually only come to the surface during nightmares and dreams. This necessity to transcend ordinary conceptions of beauty, was also important to Victor Frankenstein, who was the victim of a malignant desire inevitably caused by his "sleep of reason" which led him to confess that "My attention was fixed upon every object the most insupportable to the delicacy of the human feelings" (Shelley, 1996, p. 30). Sherman (1995) also explained, in a 1997 interview, that she started creating these images of abjection and monstrosity in an effort to examine more deeply and transcend ordinary conceptions of beauty:

I like making images that from a distance seem kind of seductive, colorful, luscious and engaging, and then you realize what you are looking at is something totally opposite. It seems boring to me to pursue the typical idea of beauty, because that is the easiest or the most obvious way to see the world. It's more challenging to look at the other side.

\section{Conclusions}

Kiki Smith, Abigail Lane, and Cindy Sherman, like Mary Shelley, have never tried to find the easiest way to see the world, because their interest was to look at the darkest side, our monstrous side, ourselves. They all seem to consider that producing horrific art can serve as a type of exorcism because "while making the scariest things we can place them outside us, to protect our own internal psychic being” (as cited in Posner, 2005, p. 23). Their creative monstrosities, whose beauty depend on the deformity of their appearance, reveal the paradox of creation by presenting their art as monsters, or as something at the same time very personal and very independent or even alien. Like Mary Shelley romantic writing, these works seem to possess an apparently circular self-reference, but they enter into a wider domain of significance which aspires to the universal, showing a deep human engagement with the world. Following Frankenstein's advice, these women artists also poured "a torrent of light into our dark world" and "disturbed, with profane fingers, the tremendous secrets of the human frame” (Shelley, 1996, p. 30).

\section{References}

Baldick, C. (1987). In Frankenstein's Shadow—Myth, monstrosity, and nineteenth-century writing. Oxford: Oxford University Press.

Botting, F. (1995). (Ed.). Frankenstein. New York: Palgrave.

Brown, N. (2001). Art from the UK. Munich: Sammlung Goetz.

Carroll, N. (1990). The philosophy of horror, or paradoxes of the heart. New York: Routledge.

Creed, B. (1993). The monstrous-feminine: Film, feminism, psychoanalysis. New York: Routledge.

Cruz, A., \& Smith, E. A. T. (2001). Cindy Sherman—Retrospective. New York: Thames \& Hudson.

Freud, S. [1919]. (1990). “Das Unheimliche”, Art and Literature. The Penguin Freud Library, 14, Harmondsworth: Penguin 
Grosenick, U. (2001). (Ed.). Women artists in the 20th and 21st century. London: Taschen.

Grunenberg, C. (1997). Transmutations of horror in late twentieth century art. Boston: The Institute of Contemporary Art.

Kelley, M. [1993]. (2004). The uncanny. Retrieved from http://www.tate.org.uk/whats-on/tate-liverpool/exhibition/mike-kelley-uncanny

Lane, A. (1993). The incident room. Retrieved from http://abigaillane.co.uk/menu-artworks.php?show=9\&img=5

Lane, A. (2001). Tomorrows World. Yesterdays Fever (Mental Guests Incorporated). Retrieved from http://www.mkgallery.org/shop/product/abigail_lane

O’Reilly, S. (2009). The body in contemporary art. London: Thames \& Hudson.

Posner, H. (2005). Kiki Smith. New York: The Monacelli Press.

Shelley, M. [1818 ]. (1996). Frankenstein (A Norton Critical Edition). J. P. Hunter, (Ed.). New York: Norton.

Sherman, C. (1995). Interview in Journal of Contemporary Art. Retrieved from http://www.jca-nline.com/sherman.html Smith, K. (1990). Untitled. Retrieved from http://www.all-art.org/art_20th_century/smith1.html Smith, K. (1992). Virgin Mary. Retrieved from http://www.all-art.org/art_20th_century/smith1.html Smith, K. (1993). Bloodpool. Retrieved from http://www.all-art.org/art_20th_century/smith1.html Smith, K. (1995). Interview in Journal of Contemporary Art. Retrieved from http://www.jca-online.com/ksmith.html Smith, K. (1995). Interview in Journal of Contemporary Art. Retrieved from http://www.jca-online.com/ksmith.html Smith, K. (2002). Born. Retrieved from http://www.all-art.org/art_20th_century/smith1.html Tillman, L. (1992). The madame realism complex. New York: Columbia University. 